\title{
In vitro Studies on Oviposional Preference of Pomegrante Fruit Borer (Deudorix epijarbas)
}

\author{
Sajad Mohi-ud-din ${ }^{1 *}$, F.A. Zaki ${ }^{2}$, M. Jamal Ahmad ${ }^{1}$ and M.A. Malik ${ }^{1}$
}

${ }^{1}$ Division of Entomology, Sher-e-Kashmir University of Agricultural Science and Technology, Kashmir, India

${ }^{2}$ Faculty of Horticulture, SKUAS-K, Shalimar, India

*Corresponding author

\section{A B S T R A C T}

Keywords

Deudorix epijarbas,

Pomegranate,

Oviposittion

Article Info

Accepted:

24 February 2018

Available Online:

10 March 2018
An experiment was performed on ovipositonal preference of females of Anar butterflies (Deudorix epijarbas) under laboratory condition in the Division of Entomology, SKUAST-K, Shalimar during 2012. Studies revealed that adult female laid eggs on flowers, fruits and also on stalk and leaves within the vicinity of fruiting parts. More number of eggs (63.75) were laid on 30-40 days old fruits with a percentage $(52.46 \%)$ mainly on calyx cup followed by 19.00 laid on matured fruits, which accounts for 5.63 per cent. Other plant parts viz., flower buds, fully opened flowers, leaves, stalk and fruit let stage were least preferred by D. epijarbas adults for oviposittion.

\section{Introduction}

Pomegranate (Punica granatum L.) is a nonclimacteric table fruit relished for its delicacy and nutritive value. It belongs to genus Punica and family Punicaceae. Pomegranate contains 1.6 per cent proteins, 0.1 per cent fats, 0.7 per cent minerals, 14.6 per cent carbohydrates, 0.3 per cent iron and $16 \mathrm{mg}$ of vitamin $\mathrm{C}$ per 100 gm of fruit (Banker, 1988; Bose). In addition to 78 per cent moisture, the fruit is reported to contain 5.1 per cent fiber, $10 \mathrm{mg}$ of calcium, 5 $\mathrm{mg}$ of phosphorus and $0.3 \mathrm{mg}$ of nicotinic acid. Dietary supplementation with pomegranate is believed to prevent cancer
(Afaq et al., 2003). Many pests including 91 insects, 6 mites and 1 snail have been reported on pomegranate. The most obnoxious pest is pomegranate butterfly, Deudorix (=Virachola) isocrates Fab., also called as anar butterfly or pomegranate fruit borer which may destroy more than 50 per cent of fruits (Balikai et al., 2011). Severe infestation of fruit borer has resulted in the reduction of pomegranate yield as well as cultivation of the fruit in the country.

In Kashmir, an allied sps. of this insect, Deudorix epijarbas (Moore) has been recorded as a serious and predominant pest of 
pomegranate fruits (Zak-ur-Rab, 1980). The pest is a worst enemy of pomegranate fruits cultivation in Himachal Pradesh and Jammu and Kashmir. The pest attacks fruit from early stages till maturity of the fruit. The caterpillar bore into developing fruits and feed upon the pulp and seeds causing fruit drop, resulting into rotting of fruits due to secondary attack of fungi and bacteria and making the fruit unfit for human consumption. The damage caused by infestation affects the quality of fruits which renders them unfavorable for market.

The status of this pest and its extent of damage to the crop in Kashmir valley have not been fully studied so far. Therefore, for developing a sound pest management system, a basic knowledge on biology of the pest is essential. The fruit is popular as a kitchen garden fruit; therefore, use of insecticides is not feasible, causing toxic and environmental hazards. Ecofriendly and sustainable methods of pest control is the need of the present times.

Only chemical management of this pest has been tried in Kashmir and no IPM strategies have been developed so far. There is an urgent need to develop management strategies of pomegranate fruit borer which are more in harmony with environment. The increasing importance of pomegranate and pervasive nature of $D$. epijarbas and change in philosophy from chemical control to integrated pest management, have necessitated to undertake studies on the pest with the following objectives:

\section{Materials and Methods}

An experiment was performed on ovipositional preference of females of Anar butterflies in cages (18'x $\left.18^{\prime \prime} \times 18^{\prime \prime}\right)$ under laboratory condition (at ambient room temperature and relative humidity) the Division of Entomology, SKUAST-K, Shalimar during 2012. Care was taken to tag the young flower buds with the date of emergence. Accordingly, the age of the fruit was calculated from the date of bud emergence. Five numbers of each of the below mentioned plant parts were kept randomly in each cage. Five pairs (laboratory reared population) of adults were released in each cage for free choice oviposition. Adult butterflies were fed with $50 \%$ honey solution for maintenance.

\section{Different parts of plant material}

Flower bud

Flower

Fruit let stage (10-20 days)

Young fruit (30-40 days)

Stalk

Leaves

Mature fruits

No. of adult pairs/replication: 05

No. of Replications: 04

Design of Experiment: CRD

\section{Results and Discussion}

The present investigations on the ovipositional behaviour of fruit borer (Deudorix epijarbas) revealed that adult female laid eggs on flowers and fruits and also on stalk and leaves within the vicinity of fruiting parts. The egg distribution pattern studies (Table 1) revealed that more number of eggs (63.75) was laid on 30-40 days old fruits with a percentage (52.46) mainly on calyx cup followed by 19.00 laid on matured fruits, which accounts for 5.63 per cent. Other plant parts viz., flower buds, fully opened flowers, leaves, stalk and fruit let stage were least preferred by $D$. epijarbas adults for oviposition and received 6.25 (5.14\%), 5.00 (4.11\%), 6.00 (4.93\%), $9.50(7.81 \%)$ and $12.00(9.87 \%)$ eggs, respectively. Eggs laid on flower bud, fully opened flower and leaves were at par. However, eggs received on stalk, fruit let stage, young fruit and mature fruit differed significantly. 
Table.1 Preference by D. epijarbas adults for oviposition in different plant parts

\begin{tabular}{|c|c|c|}
\hline Fruiting parts of pomegranate & No. of eggs laid & \% egg laying \\
\hline Flower bud & $6.25^{\mathrm{a}}$ & 5.14 \\
\hline Fully opened flower & $5.00^{\mathrm{a}}$ & 4.11 \\
\hline Leaves & $6.00^{\mathrm{a}}$ & 4.93 \\
\hline Stalk & $9.50^{\mathrm{b}}$ & 7.81 \\
\hline Fruit let stage & $12.00^{\mathrm{c}}$ & 9.87 \\
\hline Young fruit & $63.75^{\mathrm{e}}$ & 52.46 \\
\hline Mature fruit & $19.00^{\mathrm{d}}$ & 15.63 \\
\hline C.D(p $\leq \mathbf{0 . 0 5})$ & $\mathbf{2 . 3 6 7}$ & - \\
\hline
\end{tabular}

These findings are in consonance with similar report of Murugan and Thirumurugan (2001) and Karuppuchamy et al., (1998) who revealed that some of chemical cues present in young fruits might have attracted the lepidopterans pests to lay more eggs on them. According to Thirumurugan (1992), 30 days old fruits recorded the highest amount of amino acids and sugars. Further, D. isocrates adults preferred the calyx cup region for egg laying may be ascribed to the constant stimulants and volatiles present in that region (Thompson and Pellmyr, 1991) and lower amount of tannin and total phenolics when compared to fruits (Karuppuchamy et al., 1998).

Means followed by a common letter in a column are not significantly different at 5\% level of by DMRT

\section{Acknowledgements}

The authors wish to thank Professor and Head, Division of Entomology for providing necessary facilities during the course of experimentation.

\section{References}

Afaq, F., Saleem, M. and Mukhtar, H. 2003. Pomegranate fruit extract is a novel agent for chemoprevention: Studies in mouse skin. $2^{\text {nd }}$ Annual $A A C R$
International Conference on Frontiers in Cancer Prevention Research, 26-30 October, Cancer Epidem, and Biomar. 12: 1351-1353.

Balikai, R.A., Kotikal, Y.K. and Prassana, P.M. 2011. Status of pomegranate pests and their management strategies in India. Acta Horticulturae 890: 569-584.

Banker, G.J. 1988. Nutritive aspect of arid zone fruits and vegetables. In: Proceedings of Training Course on Management of Arid Horticulture, conducted by CAZRI Jodhpur from February 2-16, pp.11-20.

Bose, T.K. and Mitra, S.K. 1990. Fruit: Tropical and Subtropical. Naya Prakash-206, Vidhan

Karuppuchamy, P., Balasubramanian, G. and Sundra Babu, P.C. 1998. The biology of pomegranate fruitborer, Deudorix isocrates. Madras Agriculture Journal 85: 256-259.

Murugan, M. and Thirumurugan. 2001. Ecobehaviour of pomegranate fruit borer, Deudorix isocrates (Fab.) [Lycaenidae: Lepidoptera] under orchard ecosystem. Indian Journal of Plant Protection 29 (1\&2): 121-126.

Thirumurugan, A. 1992. Studies on insect pests of pomegranate (Punica granatum L.) and their control. M.Sc. (Ag.) Thesis submitted to Tamil Nadu Agricultural University, Coimbatore, p. 106. 
Thompson, J.N. and Pellmyr, O. 1991. Evaluation of ovipositional behavior and host preference in lepidpotera. Annual Review of Entomology 36: 6589.
Zaka-ur-Rab, M. 1980. The cornelian Deudorix epijarbas, Moore (Lepidoptera: Lycaenidae) as a serious pest of pomegranate fruits in Kashmir. Journal of Entomological Research 4: 233-235.

\section{How to cite this article:}

Sajad Mohi-ud-din, F.A. Zaki, M. Jamal Ahmad and Malik, M.A. 2018. In vitro Studies on Oviposional Preference of Pomegrante Fruit Borer (Deudorix epijarbas). Int.J.Curr.Microbiol.App.Sci. 7(03): 2734-2737. doi: https://doi.org/10.20546/ijcmas.2018.703.315 